Etnográfica

Revista do Centro em Rede de Investigação em

Antropologia

vol. 24 (1) | 2020

Vol. $24(1)$

\title{
"Good faith debtors" and the deservingness of debt relief during the Spanish home repossessions crisis
}

Los "deudores de buena fe" y el merecimiento de alivio para las deudas durante la crisis de las ejecuciones hipotecarias en España

Irene Sabaté Muriel

\section{(2) OpenEdition}

Journals

Electronic version

URL: https://journals.openedition.org/etnografica/8399

DOI: 10.4000/etnografica.8399

ISSN: 2182-2891

\section{Publisher}

Centro em Rede de Investigação em Antropologia

\section{Printed version}

Date of publication: 1 February 2020

Number of pages: 187-200

ISSN: 0873-6561

Electronic reference

Irene Sabaté Muriel, "'Good faith debtors" and the deservingness of debt relief during the Spanish home repossessions crisis", Etnográfica [Online], vol. 24 (1) | 2020, Online since 25 February 2020, connection on 19 January 2022. URL: http://journals.openedition.org/etnografica/8399 ; DOI: https:// doi.org/10.4000/etnografica.8399

\section{(c) (i) (8)}

Etnográfica is licensed under a Creative Commons Attribution-NonCommercial 4.0 International License. 


\section{"Good faith debtors" and the deservingness of debt relief during the Spanish home repossessions crisis}

\section{Irene Sabaté Muriel}

In the early years of the recent economic crisis in Spain, as the rate of mortgage default began to raise, hegemonic discourses depicted defaulting debtors as having lived "beyond their means," and therefore as culprits of their own situation. From 2009 on, given the huge scale of the phenomenon and promoted by anti-repossessions movements, an alternative narrative emerged: the crisis was redefined as a collective scam perpetrated by banking elites, with the complicity of public authorities. The tension between both narratives sets the basis for moral judgements that establish the deservingness of different forms of debt relief and material support. The categorisation of debtors as "deserving" or "undeserving" may either be defined by law, or result from assessments made by welfare institutions, bank employees, members of the anti-repossessions movement, debtors' social networks, and debtors themselves. However, not all of these judgements have equal chances to turn into actual access to debt relief.

KEYWORDS: deservingness, indebtedness, mortgage default, home repossessions, debt relief, economic crisis in Spain.

Los "deudores de buena fe" y el merecimiento de alivio para las deudas durante la crisis de las ejecuciones hipotecarias en España - En los inicios de la reciente crisis económica en España, cuando las tasas de morosidad hipotecaria comenzaron a dispararse, los discursos hegemónicos representaban a los deudores que impagaban como personas que habían vivido "por encima de sus posibilidades" y, en consecuencia, como culpables de su propia situación. A partir de 2009, dada la gran escala del fenómeno y fruto de la actividad de los movimientos anti-desahucios, apareció una narrativa alternativa. La crisis se redefinió como una estafa colectiva perpetrada por las élites bancarias, con la complicidad de las autoridades. La tensión entre ambas narrativas constituye la base de juicios morales que establecen el merecimiento de distintas formas de alivio de las deudas y apoyo material. La categorización de los deudores como "merecedores" o "inmerecedores" puede provenir de definiciones legales o resultar de los juicios emitidos por las agencias proveedoras de bienestar, los empleados bancarios, los miembros de los movimientos anti-desahucios, el entorno social de los deudores, o los deudores mismos. No obstante, no todos estos juicios tienen la misma capacidad de mitigar de forma efectiva el endeudamiento.

PALABRAS CLAVE: merecimiento, endeudamiento, morosidad hipotecaria, ejecuciones hipotecarias, alivio de las deudas, crisis económica en España.

SABATÉ MURIEL, Irene (sabate.irene@gmail.com) - Department of Social Anthropology, University of Barcelona, Spain. 


\section{FROM BLAMING DEBTORS TO BLAMING ELITES, AND CLAIMING} FOR SOLUTIONS

In the early years of the current economic crisis in Spain, as the rate of mortgage default began to raise, hegemonic discourses depicted defaulting debtors as having lived "beyond their means," and therefore as culprits of their own situation. ${ }^{1}$ The phenomenon of home repossessions was widely perceived as a marginal one, only affecting borrowers who had over-estimated their purchase power and job stability, or who had failed to resist the temptations of available credit that gave access to conspicuous consumption, as well as to the purchase of over-valued properties during the housing bubble. Their aspiration at material living standards higher than those traditionally attributed to their social condition was then seen as illegitimate. The public debate on this issue was a rather simplistic one.

This under-representation of over-indebtedness in the public sphere went on for a while. However, already in 2008, repossessions raised to 58,686, more than twice the number in the previous year, ${ }^{2}$ and the rate of default amounted to $2.37 \%$, more than three times the rate in $2007 .^{3}$ Although bank managers started to be worried, at the beginning they tended to put off the problem through a variety of strategies. ${ }^{4}$ At that time, virtually no public voices, except for some critical scholars (Naredo 2009; López and Rodríguez 2010), questioned the widely spread discourses that blamed mortgagors for their misfortune. Home repossessions remained out of the public eye as long as they only reached the most vulnerable and isolated mortgage debtors, those who had accessed home ownership despite their precarious positions in the job market, as it was the case for migrant workers (Palomera 2013; Suárez 2014; Terrones 2013; Lundsteen and Sabaté 2018).

Nevertheless, as the phenomenon escalated in a few months' time, serious doubts about its limited reach started to emerge. The initial moral panic and stigma attributed to mortgage default would be qualified by the emergence of an alternative narrative about the mortgage crisis in the subsequent years. Home repossessions and evictions started to be perceived as particularly

1 The article is based on research developed within the project "Popular Notions of Social Justice in the Face of the Crisis and Austerity Policies" (CSO2015-67368-P), funded by the Spanish Ministerio de Economía y Competitividad and the European Regional Development Fund (Feder), 2016-2018.

2 See "Efectos de la crisis en los órganos judiciales," Consejo Superior del Poder Judicial, available at < http://www.poderjudicial.es/cgpj/es/Temas/Estadistica-Judicial/Estudios-e-Informes/Efecto-de-la-Crisi s-en-los-organos-judiciales/ $>$ (last access in February 2020).

3 See "Informe de estabilidad financiera," May 2009, Banco de España, p. 25, available at < https:// www.bde.es/f/webbde/Secciones/Publicaciones/InformesBoletinesRevistas/InformesEstabilidadFinance ra/09/Fic/IEF200905.pdf > (last access in February 2020).

4 Such as, for example, the concession of grace periods for debtors facing economic difficulties, so that no default could be detected in the bank's accounting books. 
salient and unprecedented manifestations of the deep economic and financial crisis that has struck the country for more than a decade now. The depiction of defaulting debtors as liable for their inability to repay their loans was thus challenged by a resignification of mortgage default and home repossessions as symptoms of a structural, collective scam that led to a state of popular indignation. Financial institutions started to be accused of their greed and predatory practices, and public authorities were perceived as their accomplices, as they would not modify a legal framework, particularly the Mortgage Act, that kept defaulting debtors in a helpless situation even after their eviction. They could remain indebted for life. The compliance with the law and with the stipulations of loan contracts, as well as the preservation of property rights and the obligation to repay beyond any other consideration, started to be questioned.

Spontaneous expressions of indignation would evolve with the articulation and crystallization of social movements such as the Plataforma de Afectados por la Hipoteca (PAH, Coalition of People Affected by Mortgages), created in 2009 in Barcelona, and would rapidly expand to the rest of the country. The movement would reach momentum in the following years, successfully combining direct action against banks, civil disobedience in front of evictions, mutual counsel and support among mortgagors, and proposals of legal and policy modifications to legislators and public authorities (Colau and Alemany 2012; Suárez 2014; García-Lamarca and Kaika 2016; Sabaté 2014). The movement would increase its legitimacy and gain public support after the bailout of financial institutions by the Spanish state, as it happened in 2012 when more than 22 million euros were transferred to Bankia.

This alternative narrative highlighted the role of financial and political elites in the origination of the crisis, therefore attributing them responsibility as blame, or liability. But, beyond that, claims concerning responsibility as task, or accountability (King 2006: 116), started to arise too. ${ }^{5}$ Who was to be attributed the responsibility to remediate the impacts of the spate of repossessions and evictions? In the face of a social emergency, anti-repossessions movements and other critical voices tasked certain social actors - public authorities, policy makers, judges, and creditors themselves -with its remediation, claiming for the implementation of several forms of debt relief for households facing a repossession, and housing provision for those already evicted. ${ }^{6}$

5 For King (2006: 116), this opposition entails the distinction between two different senses of responsibility. In the first sense, being responsible is where one is taken to be the primary cause of a particular situation. One is responsible because the situation would not have arisen but for one's actions or omissions. In the second sense, one is deemed to be the person (or the organisation) who is tasked with dealing with an issue, either by initiating or guiding some activity, or in the more negative sense of clearing up some problem that has arisen under one's jurisdiction.

6 It is interesting to observe that another crucial actor, real estate agencies and other intermediaries who had played a role in the housing bubble, were not pointed at as responsible to the same extent. 
Debtors like Salvador expressed this attribution of responsibility after losing his flat and putting his parents-in-law, who had acted as guarantors, at risk of losing theirs too:

"In fact I am not totally guilty, so let them [the bank] assume their part. I am already suggesting a solution. Then do it too [you, the bank]. I am yielding in the negotiation: take one of the two flats. My father-in-law or me will lose our property. But do not make it harder for us, we have had enough. I have failed my family, I have not been able to cope with everything. That is already hard for me to assume. But do not keep punishing me. I have assumed my part of fault."

In all, since the end of the housing bubble, we have witnessed an evolution from the hegemony of discourses blaming defaulting debtors for their fate, to the emergence of a counter-narrative of the crisis as a collective scam, where creditors and public authorities were depicted as liable for over-indebtedness and default. The latter has come hand in hand with the claim for tangible, urgent support for the victims of the crisis, in the form of debt relief and/ or alternative accommodation arrangements. Such a claim, in the context of scarce welfare provision and given the reluctant attitudes and legal impunity of creditors, as well as the lack of legal stipulations for the support of defaulting debtors, ${ }^{7}$ opens up what will be the central questions to this paper: What are the criteria for giving or denying access to debt relief and to an alternative housing solution for defaulting mortgagors? Who deserves to be accorded a way out of indebtedness and homelessness? Who and what defines such deservingness, which entails a judgement based on moral concerns? And, among all actors making such judgements, who has the ability to turn them into imperatives to action?

In the following sections, drawing on ethnographic evidence collected in the metropolitan area of Barcelona from 2012 to 2015, we approach the case of home repossessions in Spain through the lens of deservingness assessments. It is our aim to shed light into the moral, ideological, and practical aspects of the production and reproduction of social cleavages in a late capitalist society during a severe economic and social crisis.

7 Contrary to what happens to firms: for some years into the crisis, bankruptcy law only existed for them, while personal insolvency was not regulated until 2015 (cf. "Ley 25/2015, de 28 de julio, de mecanismo de segunda oportunidad, reducción de la carga financiera y otras medidas de orden social”). 
WAYS OUT OF THE MORTGAGE CRISIS:

\section{DEBT RELIEF AND ALTERNATIVE HOUSING}

Before addressing the definition of defaulting mortgagors as deserving or not deserving a solution for their desperate situation, let us describe what such a solution may consist on. Indeed, welfare policies in Spain do not include a comprehensive approach to indebtedness and default as contingencies to be remedied by the State, and the Mortgage Act does not define creditors' responsibilities in this regard. Rather, throughout the recent period of economic crisis, the legislation established the right of banks to claim for the whole outstanding debt after three months of arrears. ${ }^{8}$ The repossession process could then be initiated, leading to the auction of the property. The financial institution itself can purchase it for at least 70\% of its value, ${ }^{9}$ leaving the mortgagor indebted for the rest, plus late payment interest and the legal costs of the process. As a result, most debtors lost their homes and, even after their eviction, a considerable part of their debt remained.

Before that, during and after the repossession process, defaulting debtors may seek for an arrangement that allows them to keep their properties, for instance by adjusting the conditions of repayment in order to make it affordable for them. These forbearance schemes are typically agreed upon as debtors at risk of default approach their bank and ask for a solution, a frequent situation during the first years of the crisis. However, as anti-repossessions activists have argued, such schemes have rarely entailed a real solution for debtors, given the rapid impoverishment of households brought about by long-term unemployment, illness, or other adverse circumstances. Hernán, who lost his building company and became trapped in debts, told us his experience in these terms:

"We went to the bank to ask for a reduction of our monthly repayments [...]. They charged us with the fees of the public notary and increased the repayment period to 47 years, so my sons would have to pay it off. But, of course, you are desperate and you sign and think, we will see. Six or seven months later, we could not repay anymore and here we are. We were evicted in October 2012 , very quickly."

When the unsustainability of the mortgage debt becomes evident, a quest to have it cancelled starts. This can happen before the repossession process is

8 This period has been extended in 2019.

9 This amount has varied over time: it was 50\% of its value at the beginning of the crisis, then $60 \%$, and more recently it was set at 70\%. This percentage does not refer to the property's value at the moment of purchase, but to an appraisal made just before the auction, when the real estate market has already experienced a devaluation. As a result, the outstanding debt remains considerable, and keeps on strangling debtors' household economies even after eviction. 
completed: at that moment, debtors may ask the bank for the cancellation of their loan in exchange for the property. This refers to a legal notion, "assignment in payment," 10 that was not included in legislation at the beginning of the crisis, and that has now been defined in more recent decrees as a mere possibility, a "good practice" that is advisable in certain cases, but that entirely depends on the willingness of the creditor, as debtors are not acknowledged as entitled to it on a comprehensive basis. Likewise, after the auction of the property and the eviction of its inhabitants, the latter may try to have their outstanding debt cancelled in order to remake their lives. This possibility, too, is completely subject to the bank's final discretion, except for a few debtors meeting very strict requirements allowing them to resort to a bankruptcy trial, a possibility that did not exist at all until a timid "second opportunity law" was passed in 2015. ${ }^{11}$ The discretionality of debt cancellation, its complete dependence on creditors' approval, explains why, in contrast to what has happened in other countries like the US (Jefferson 2013), strategic defaulting is not seen as an option by Spanish debtors.

In addition, former mortgagors who are about to lose their homes, or who have already lost them, may apply for an alternative accommodation arrangement. In some cases, they have managed to remain in their former properties in exchange for an affordable rent to be paid to the bank who has now acquired the unit. In other instances, debtors may try to access an alternative housing unit, for example by applying for social housing - a very scarce resource in Spain -, or by squatting vacant housing, in some cases with the support of social movements.

All these arrangements, that we have labelled as forms of "debt relief," may be reached through a variety of strategies, all of them in the framework of the asymmetric relationship between creditor and debtor, of the enduring effects of mortgage loan contracts signed under completely different circumstances, and of the financial dynamics that take place beyond ordinary people's control - and often understanding. Some of these strategies involve the intervention of other actors - a public welfare institution, an anti-repossessions movement, a third-sector organization, a public defender, a judge who passes sentence. All of these actors, we contend, rather than unconditionally supporting mortgagors in hardship, condition their action to an assessment of mortgagors' deservingness to find their way out of a critical situation.

10 "Dation in payment" seems to be another possible translation of the Spanish term dación en pago.

11 See footnote 7 . 


\section{ASSESSING DESERVINGNESS}

According to our data, the categorisation of debtors as deserving or not deserving support in the form of debt relief and housing alternatives is a ubiquitous practice. Since the beginning of the crisis, different sets of people, either as individuals or as representatives of institutions, have been assessing the past and present behaviour of defaulting mortgagors in the aim of making such distinction. Welfare institutions (public agencies or non-profit organisations), bank employees, members of the anti-repossessions movement, the social networks where debtors are embedded, and debtors themselves, have engaged in the assessments of deservingness. The scarcity of welfare provision in the form of benefits and social housing have contributed to foster this practice, and the lack of legal stipulations for the support of defaulting debtors has introduced a great degree of arbitrariness.

The criteria on which such assessments are founded may either be explicitly defined by law - as in the legal notion of the "good faith debtor" 12 - , or result from more implicit criteria. The latter include a wide range of aspects such as tangible proofs of individual effort and merit, a responsible attitude as heads of their families, compliance to well-established social norms such as showing a docile and modest attitude while applying for assistance, observance of strict bureaucratic rules and protocols, engagement with collective action within social movements, or the accreditation of certain kinds of social disadvantage specified in legislation and welfare policies.

In their quest for debt relief and access to housing, defaulting mortgagors need to meet this set of requirements if they aspire at being judged as deserving. For example, in November 2012, a decree put off evictions for a two-year period in the case of "particularly vulnerable households," who were defined as follows:

a) large families (with three or more young children);

b) single-headed households in charge of two children;

c) households including an infant under three;

d) households with a member who is disabled, dependent, or with an illness that prevents him/her from having a job;

e) households where the loan holder is unemployed and has exhausted unemployment benefits;

f) households where the housing unit is shared with one or more (up to third-degree) relatives who are disabled, dependent, or have a serious illness that prevents them from having a job;

12 The requirements to be considered a "good faith debtor" are detailed in the 2015 law (cf. "Ley 25/2015, de 28 de julio, de mecanismo de segunda oportunidad, reducción de la carga financiera y otras medidas de orden social"). 
g) households including a victim of gender violence, if the collateral is their first residence. ${ }^{13}$

As it could be expected, this measure had a very limited reach, due to the extremely narrow conditions that it set. For this reason, it was an object of criticism not only by debtors themselves and by anti-repossession movements, but also by progressive judges such as Diego Gutiérrez, who told us about an appeal he had made for this reason:

"Of course, together with other colleagues, I have appealed to the International Human Rights Court, regarding their sentences on conventions for the protection of children, so that repossessions involving children over three were cancelled too. I have passed orders to cancel two or three processes with four-, five- or six-year-olds. We need to resort to international law or to international courts in order to reach fairer solutions. It does not seem sensible to me that you cannot repossess a three-year-old, but you can do it to a four-year-old."

In the case of bank employees negotiating with debtors, as long as the legislation did not force them to grant debt relief in the event of default and insolvency, decisions have been rather arbitrary, or subject to a variety of factors that we will not examine here. ${ }^{14}$ In certain moments, employees have resorted to the "good debtor" imaginary in order to dissuade debtors from quitting repayments as they met hardship, trying to convince them to keep making efforts to avoid default, or offering them forbearance schemes instead of the assignment in payment, so that they would not go into arrears yet. In contrast to that "good faith," bank employees criticised customers who showed no inclination to assume their financial obligations. Miquel, the former director of a bank's mortgages center, described these customers as follows:

13 Cf. "Real Decreto-ley 27/2012, de 15 de noviembre, de medidas urgentes para reforzar la protección a los deudores hipotecarios" (our translation and adaptation). In a similar vein, a previous decree enacted in March 2012 advised banks to grant the assignment in payment to debtors who met the following requirements: (a) no member of the household should be getting a wage or other remuneration; (b) monthly repayments of the mortgage loan should amount to more than $60 \%$ of the total income of the household; (c) the members of the household should not have any other properties or goods to cope with the debt; (d) the collateral of the mortgage should be the first residence of the household; (e) there should be no guarantors to the mortgage loan or, if they existed, they should meet all these requirements as well; (f) if there were other joint holders of the loan outside the household, they should also meet requirements (a), (b) and (c).

14 Including, for example, the evolution of property values, financial operations affecting the bank itself, changes in management strategies over time, as well as the impact of particular campaigns carried out by social movements on the image of banks (Sabaté 2016a, 2016b). 
"I don't know, perhaps I was in the crappiest and most rotten point of the bank's network, but I did not meet that profile described by Ada Colau, ${ }^{15}$ the poor family who cannot pay and cries and is desperate. I only saw lazy people [penca]. Migrants who did not understand you if they were not interested [...]. They didn't give a fuck."

This "good/bad debtor" dichotomy can also be traced in the accounts of some mortgagors, who, like Ramon, a former small entrepreneur who lost his firm and his house, insisted in identifying himself in that way, even after experiencing the empowering effect of activism:

"I am not a professional defaulter, I have become insolvent due to life circumstances, you know? Had my firm gone bankrupt at another time, and I would have been able to replace it by a job, I would have been able to keep on repaying, but I simply cannot do it."

Esteban, a former self-standing plumber who had to quit his job due to a heart disease, and who is now facing repossession and eviction, used a similar argument about his honest intention to face his financial responsibilities if he could afford it:

"If we are not repaying the mortgage is because we cannot do it, not because we don't want to. And I am going to keep repaying other things. But the mortgage, that I cannot. Because I can no longer work as I used to."

We also notice a determination to depict himself as an honest worker in Salvador's account:

"I want people to know that we are neither outcasts, nor are we in this situation because we want to. We are workers, ordinary people, who, until yesterday, did not think that this could happen to us, and one day, due to uncontrollable circumstances, you realise that you are in this."

Welfare agents also tend to distinguish this model of a hard-working person with no previous experience of asking for welfare or guidance, who has been caught by surprise in adverse circumstances, from their regular clients. In the accounts of agents, a narrative emerges on the crisis becoming chronical and reaching the middle classes who reluctantly start to visit the social services as their last resort. Jordi, a retired bank employee who now volunteers as a counsellor for mortgage defaulters at a charity organisation, told us about this contrast: 
"This is not only affecting migrants, our statistics show that most people are nationals. People who had lived well, who had a good wage and would have never imagined they would go to social services or come here asking for help, are coming now. Other better-off layers are being touched. People who do not know the circuits of social services."

At the same time, welfare agents dislike the attitudes of some clients who do not show enough regret, after having acted as risky investors during their years of prosperity. Jordi recalled the following case:

"We met someone who had signed a loan in yens. He had acted as a know-it-all. A small entrepreneur whose properties had been seized. We gave him advice, but he came like [he mimes an arrogant attitude]. His wife was humbler, but he was... Of course, yens were depreciated. He knew, he was not ignorant [...]. You all are borrowing in euros, I am borrowing in yens. He was the kind that went to dinner with friends and said, look at me..."

According to this, new clients who had never been dependent on welfare provision, who try hard to find their way through bureaucracy - a task that requires a considerable amount of time and resistance to frustration (Azis 2016) -, and who assert their will to recover their autonomy, are more likely to arouse the sympathy of welfare agents, who act as gatekeepers in the access to advice and support (Dubois 2018).

Interestingly, the deserving-undeserving dichotomy does not only operate in the field of welfare provision. According to our data, anti-repossession movements also act to some extent on the basis of deservingness assessments, although they are guided by a different set of criteria. In order to be supported in their battle against banks, participants need to show commitment and to focus on the interests of the collective, rather than on their own. In this way, they fit in the model of what Gutiérrez-Garza (2017) has called the "good activist," and so one day they acquire enough legitimacy to ask other members, for instance, to help stop their eviction. Otherwise, when people approach the assemblies in a more utilitarian way, and especially when it becomes common knowledge that they are acting simultaneously in several fronts, they tend to be considered disloyal.

As we have seen, assessments about deservingness are not uniform, but founded on diverging requirements and criteria, as they are applied in different situations and by different sets of people. Thus, they are shaped by the different social positions of the social actors expressing them, and may also vary over time. In addition, they may also be mutually conflicting: for instance, a very committed member of an anti-repossessions movement may be considered as deserving solidarity from his/her fellow activists. From a certain 
viewpoint, he/she can be seen as a responsible parent who fiercely defends his/ her family's livelihood with the decision to go into arrears and to prioritise the purchase of basic products such as food or school equipment. But, at the same time, the reluctance to accept the forbearance scheme offered by the creditor may prevent him/her from obtaining a favourable sentence from a judge, as not all the available possibilities have been exhausted before defaulting. Finally, the empowering experience of joining the social movement, often including a radical resignification of squatting practices, may prevent such a debtor from fitting into some representation of a deserving client in the eye of the welfare agent who will be filing his/her application for social housing. The outcome of such a complex combination, the transformation of deservingness into actual access to resources - in the form of debt relief or of alternative housing - will be our concern in the next and final section.

\section{THE EFFECTIVENESS OF DESERVINGNESS, AND ITS REPLACEMENT} BY UNCONDITIONALITY

As we have seen, during the mortgage crisis in Spain, virtually all social actors have engaged in assessing mortgagors' deservingness to obtain debt relief and/ or alternative housing. However, another important aspect should be taken into account: not all of these social actors have the same power to transform their assessments into actual support or resources. In other words, assessments about deservingness are unevenly effective, depending on the relative power of actors.

As a rule, judges, welfare agents and bank employees - especially those in managerial positions -, as well as politicians and legislators making decisions in this arena, are the most likely to have an effect on debtors' financial situation and housing conditions. It is not, however, a mere question of access to resources. Acting as gatekeepers to resources and support, these dominant actors produce and reproduce ideological representations of deserving and undeserving debtors. Their discourses and practices contribute, for instance, to the legitimation of austerity policies and financial deregulation, as well as, specifically in the Spanish context, to the perpetuation of the lack of accountability of the State regarding housing provision. This runs parallel to the construction of debtors as neoliberal subjects (Lazaratto 2012) who are expected to prioritise their financial obligations over other concerns, to individually assume the consequences of their failure to honour contracts, and to take care of themselves as they navigate economic hardship.

We are not suggesting, however, that deservingness assessments made by less powerful actors do not have an effect on debtors' lives. On the contrary, they may also hinder or foster their chances to recover from financial hardship, and to keep on satisfying their needs and pursuing their aspirations. Thus, in 
the everyday practice of anti-repossessions movements, assessments of deservingness are also at play, although their criteria are - implicitly - defined in completely different ways. The fact is that debtors do not receive the energy, experience and support of the movement in a completely unconditional manner, but depending on whether they are seen as sufficiently engaged in collective action and mutual help practices. A condition that not every person approaching the movement is ready to comply with, for a variety of reasons - among them, conflicts with other obligations towards kin, the lack of time available (Azis 2016) and, in some cases, an individualistic and utilitarian attitude that matches the neoliberal subject described above.

Things are different, however, as we consider members of debtors' informal social networks. Many of our informants described the tension between the blaming discourses - as well as the blaming silences - of their kin, which apparently contrasted with the actual support that they were receiving from them, for example in the form of accommodation, material resources, care giving, or financial aid. As they told about their repossession experience, they often described how relatives who had initially blamed them for their failure, and who still did it sporadically or in a more implicit manner, had nevertheless gone beyond blaming and attributions of responsibility, and were in fact providing them with unconditional support - even if this rarely happens free of conflict and tensions. Merit and deservingness, in those cases, seem to have been put on hold for the sake of generalised reciprocity within kin networks.

From this point of view, the deservingness notion seems a useful tool in our attempt to illuminate the moral aspects of welfare provision, of the administration of justice, or of the so-called "corporate social responsibility" of financial elites and institutions. But, beyond that, it may also call into question the allegedly universalist approach of anti-repossession movements. In all these cases, deservingness assessments, based on diverging criteria, are used to classify defaulting debtors into two categories: those deserving and those not deserving the allocation of resources that are perceived and/or depicted as scarce. Such assessments are, in addition, strongly dependent on moral principles that are subject to variability across social groups and along historical processes, and are not necessarily consistent with institutionalised entitlements or positive rights. As opposed to it, our ethnography has run into other forms of support, typically those channelled by kin networks and more personalised and permanent social bonds. In the event of a social emergency affecting network members, deservingness assessments seem to be put aside in the name of moral obligation and unconditionality. 


\section{REFERENCES}

AZIS, Georgios, 2016, Rising Up against the Subordination of Life in Barcelonès: An Ethnography of the Struggle of the "Afectadas" for a Future without Debt Chains, Uppsala, Uppsala Universitet, masters' dissertation, available at < http://www. diva-portal.org/sma sh/get/diva2:903456/FULLTEXT01.pdf > (last access in February 2020).

COlAU, Ada, and Adrià AlemANy, 2012, Vides Hipotecades: De la Bombolla Hipotecària al Dret a l'Habitatge. Barcelona, Angle.

DUBOIS, Vincent, 2018, El Burócrata y el Pobre: Relación Administrativa y Tratamiento de la Miseria. Valencia, Institució Alfons El Manànim.

GARCÍA-LAMARCA, Melissa, and Maria KAIKA, 2016, "'Mortgaged lives': the biopolitics of debt and housing financialization", Transactions of the Institute of British Geographers, 41: 313-327.

GUTIÉRREZ-GARZA, Ana, 2017, "The moral contradictions of social justice within the PAH", paper presented at the conference of the Federación de Asociaciones de Antropología del Estado Español, Valencia.

JEFFERSON, Anna, 2013, "Narratives of moral order in Michigan's foreclosure crisis", City \& Society, 25 (1): 92-112.

KING, Peter, 2006, "What do we mean by responsibility? The case of UK housing benefit reform", Journal of Housing and the Built Environment, 21 (2): 111-125.

LAZARATTO, Maurizio, 2012, The Making of the Indebted Man: An Essay on the Neoliberal Condition, Los Angeles, Semiotext(e).

LÓPEZ, Isidro, and Emmanuel RODRÍGUEZ, 2010, Fin de Ciclo: Financiarización, Territorio y Sociedad de Propietarios en la Onda Larga del Capitalismo Hispano (1959-2010). Madrid, Traficantes de Sueños.

LUNDSTEEN, Martin, and Irene SABATÉ, 2018, “The social articulation of the crisis and political mobilisation in Spain: some reflections on the shortcomings of the new social movements", in O. Fedyuk and P. Stewart (eds.), Inclusion and Exclusion in Europe: Migration, Work and Employment Perspectives. Colchester, ECPR Press.

NAREDO, José Manuel, 2009, "La cara oculta de la crisis: el fin del boom inmobiliario y sus consecuencias", Revista de Economía Crítica, 7: 313-340.

PALOMERA, Jaime, 2013, "How did finance capital infiltrate the world of the urban poor? Homeownership and social fragmentation in a Spanish neighborhood", International Journal of Urban and Regional Research, 38 (1): 218-235.

SABATÉ, Irene, 2014, "Del país de los propietarios al país de los sobre-endeudados: reciprocidad, solidaridad y proyectos de transformación sistémica en tiempos de crisis", Ars \& Humanitas, 8 (1): 167-187.

SABATÉ, Irene, 2016a, "The Spanish mortgage crisis and the re-emergence of moral economies in uncertain times", History and Anthropology, 27 (1): 107-120.

SABATÉ, Irene, 2016b, "Mortgage indebtedness and home repossessions as symptoms of the financialisation of housing provisioning in Spain”, Critique of Anthropology, 36 (2): 197-211.

SUÁREZ, Maka, 2014, "Movimientos sociales y buen vivir: ecuatorianos en la lucha por la vivienda en la plataforma de afectados por la hipoteca (PAH)", Revista de Antropología Experimental, 14: 71-89. 
TERRONES, Albert, 2013, "Segregation, housing market segmentation and the origin of over-indebtedness: the access to homeownership by foreign migrants based on over-indebtedness", paper presented at the $25^{\text {th }}$ European Network for Housing Research Conference, Tarragona.

Receção da versão original / Original version

$2019 / 01 / 21$

Aceitação / Accepted

$2019 / 10 / 17$ 